\title{
ZABEZPIECZENIE NA NIERUCHOMOŚCI W POSTEPOWANIU KARNYM JAKO WYRAZ RÓWNORZĘDNOŚCI REGUŁ INTERPRETACJI W PRAKTYCE ORZECZNICZEJ SĄDU KARNEGO
}

\begin{abstract}
Abstrakt: Artykuł poddaje analizie instytucję zabezpieczenia na nieruchomości w postępowaniu karnym w kontekście połączenia w niej działania organów postępowania karnego w dwóch różnych procedurach i w dwóch różnych pozycjach procesowych. Zabezpieczenie następuje w zakresie tytułu wykonawczego w postaci stosownego postanowienia i wynika $\mathrm{z}$ postępowania karnego w fazie in personam. Tytuł wykonawczy uzyskany w procedurze karnej stanowi podstawę wpisu hipoteki przymusowej według regulacji procedury cywilnej do księgi wieczystej. Artykuł ma na celu przedstawienie powyższej problematyki w kontekście rozkładu ciężaru argumentacyjnego poszczególnych uczestników dyskursu wskazanej sytuacji procesowej, a także wskazanie na pragmatyczne i procesowe znaczenie reguł interpretacji w wykładni operatywnej, niezależnie od jej przedmiotu i ram instytucjonalnych. Dokonanie prawidłowego i wyczerpującego zabezpieczenia powinno umożliwić sprawną realizację zaspokojenia roszczeń Skarbu Państwa jak i pokrzywdzonych w procesie karnym, a jednocześnie wzmocnić praktyczny kontekst reguł interpretacyjnych. Rozważania niniejszego szkicu wskazują na ratio praxis postanowienia o zabezpieczeniu, które winno spełniać, aby stanowić szybkie i sprawne narzędzie postępowania karnego.
\end{abstract}

Słowa kluczowe: zabezpieczenie na nieruchomości, postanowienie o zabezpieczeniu, postępowanie karne, postępowanie cywilne, hipoteka przymusowa, rozkładu ciężaru argumentacyjnego, interpretacja semantyczna i funkcjonalna

\section{WPROWADZENIE}

Celem niniejszego szkicu jest przedstawienie najważniejszych zagadnień interpretacyjnych związanych z zastosowaniem w postępowaniu karnym instytucji zabezpieczenia na nieruchomości. Instytucja ta, wywodząca się z obszaru prawa cywilnego, służy zabezpieczeniu środków orzeczonych przez sąd w postępowaniu karnym. W artykule przedstawiono najważniejsze zagadnienia związane z zastosowaniem reguł interpretacyjnych mogących mieć wpływ na sposób rozumienia, jak i skuteczność takiego zabezpieczenia. Zasadniczym problemem tej instytucji 
jest połączenie w niej działania organów postępowania karnego w dwóch różnych procedurach i w dwóch różnych pozycjach procesowych. Samo zabezpieczenie następuje w zakresie tytułu wykonawczego i wynika z postępowania karnego $\mathrm{w}$ fazie in personam. Jednakże uzyskany w procedurze karnej tytuł wykonawczy stanowi podstawę wpisu hipoteki przymusowej według regulacji procedury cywilnej do właściwej księgi wieczystej. Sąd wieczystoksięgowy ocenia taki tytuł i dokonuje stosownego wpisu w dziale IV właściwej księgi wieczystej ${ }^{1}$. Warto przy tym podkreślić, że jakkolwiek w postępowaniu karnym prokurator czy sąd karny dokonujący zabezpieczenia stają się dominus litis procesu, to w postępowaniu cywilnym ten sam prokurator i sąd karny występować będą jako strona procesowa, która wnioskuje o odpowiedni wpis w księdze, a wystawiony przez tę stronę tytuł wykonawczy będzie podlegać ocenie sądu „trzeciego”, czyli wieczystoksięgowego. Wskazana sytuacja procesowa zakłada wielość uczestników dyskursu, rozłożenie pomiędzy nich ciężaru argumentacji oraz związek z wykładnią operatywną ${ }^{2}$.

Artykuł ma na celu przedstawienie powyższej problematyki w aspekcie pragmatycznym i proceduralnym, ukazując znaczenie reguł interpretacji wykładni operatywnej niezależnie od jej przedmiotu i instytucjonalnych ram (w niniejszym szkicu od interpretacji karnistycznej w postępowaniu wieczystoksięgowym). Przyjęty w tekście termin ,interpretacja karnistyczna"3, mimo jego operatywnego zorientowania, ma za zadanie ukazać uniwersalny sens argumentacji prawniczej dla sytuacji procesowych wykładni operatywnej w ramach różnych dziedzin prawa.

\section{ISTOTA INSTYTUCJI ZABEZPIECZENIA NA NIERUCHOMOŚCI}

Zabezpieczenie majątkowe jest środkiem przewidzianym w Kodeksie postępowania karnego ${ }^{4} \mathrm{~W}$ celu zabezpieczenia przyszłego orzeczenia na mieniu oskarżonego, jeśli zachodzi obawa, że bez tego zabezpieczenia wykonanie zapa-

1 W celu zawężenia pola rozważań autorka ogranicza się do kwestii hipoteki przymusowej, pomijając kwestię zakazu zbycia nieruchomości, który podlegałby wpisowi w dziale III ksiegi wieczystej.

2 Pojęcie rozkładu ciężaru argumentacji pochodzi z pracy T. Gizberta-Studnickiego, Rozkład ciężaru agumentacji w dyskursie interpretacyjnym, [w:] Studia z filozofii prawa, t. 2, red. J. Stelmach, Kraków 2003, s. 65-76.

${ }^{3}$ Interpretacja karnistyczna w teorii prawa nie jest formułowana pod postacią wykładni, lecz rozumiana jako „odtworzenie wiedzy prawodawcy o adresatach stanowionych przez niego norm prawno karnych"; zob. W. Partyas, Interpretacja karnistyczna. Studium metodologiczne, Poznań 1988; R. Sarkowicz, O rozumieniu spójności w interpretacji prawniczej, [w:] Teoria prawa. Filozofia prawa. Współczesne prawo i prawoznawstwo, Toruń 1998, s. 263-272; S. Wronkowska, Z. Ziembiński, Teoria prawa, Warszawa 1999; J. Wróblewski, Sądowe stosowanie prawa, Warszawa 1988; M. Zieliński, Wykładnia prawa. Zasady, reguły, wskazówki, Warszawa 2002.

${ }^{4}$ Ustawa z dnia 6 czerwca 1997 roku — Kodeks postępowania karnego, Dz.U. z 1997 r. Nr 89, poz. $555 \mathrm{ze}$ zm. 
dłego orzeczenia będzie niemożliwe albo znacznie utrudnione. Ma ono na celu zapobieżenie pozbycia się bądź ukrycia przez podejrzanego czy też oskarżonego posiadanych środków majątkowych, służących zaspokojeniu ewentualnie zasądzonych w wyroku należności majątkowych czy finansowych. Zabezpieczenie to dopuszczalne jest tylko wtedy, gdy istnieje duże prawdopodobieństwo, że oskarżony dopuścił się zarzucanego mu przestępstwa objętego zakresem zastosowania art. $291 \S 1$ k.p.k. ${ }^{5}$ Przepis ten wymienia enumeratywnie rodzaje środków, których wykonanie chroni zabezpieczenie majątkowe. Ustawodawca zalicza w ich poczet:

a) grzywnę,

b) świadczenie pieniężne,

c) przepadek,

d) środek kompensacyjny,

e) zwrot pokrzywdzonemu lub innemu uprawnionemu podmiotowi korzyści majątkowej, jaką sprawca osiągnął z popełnionego przestępstwa, albo jej równowartości.

Zgodnie z treścią art. $293 \S 5$ k.p.k. postanowienie o zabezpieczeniu majątkowym stanowi tytuł wykonawczy z chwilą wydania. Tym samym nie wymaga ono nadania mu klauzuli wykonalności 6 .

Mimo że zabezpieczenie majątkowe stanowi narzędzie procedury karnej, to jednak w myśl art. 292 k.p.k. następuje w sposób wskazany w przepisach k.p.c. ${ }^{7}$, co wiąże się $\mathrm{z}$ aspektami procesowymi i interpretacyjnymi w wykładni operatywnej dokonywanej przez organ stosujący prawo. Dodatkowym zagadnieniem jest kwestia skutecznego, sprawnego i trwałego dokonania tego zabezpieczenia na nieruchomości w sposób realizujący cele prowadzonego postępowania karnego, a więc pragmatycznego aspektu akceptowalności procesowego rozstrzygnięcia (faktycznej skuteczności interpretacyjnych argumentów stosowanych w sporze).

Faktyczne zabezpieczenie na nieruchomości nie następuje z chwilą wydania postanowienia o zabezpieczeniu $\mathrm{z}$ urzędu lub w momencie uwzględnienia wniosku prokuratora o wydanie takiego postanowienia. Zabezpieczenie na nieruchomości następuje w momencie obciążenia nieruchomości podejrzanego lub oskarżonego hipoteką przymusową, co dokonuje się poprzez wpis do księgi wieczystej zgodnie z treścią art. 109 i następnych ustawy o księgach wieczystych i hipotece ${ }^{8}$. Powyższy wpis może nastąpić na wniosek organu prowadzącego postępowanie karne, a więc prokuratora w postępowaniu przygotowawczym lub sądu w postępowaniu jurysdykcyjnym, działającym z urzędu.

5 Postanowienie Sądu Apelacyjnego w Krakowie z dnia 28 czerwca 2018 roku, I AKz 257/18, dotyczące dopuszczalności zastosowania zabezpieczenia majątkowego w procesie karnym.

${ }^{6}$ Por. J. Konecki, Zabezpieczenie majątkowe w postępowaniu przygotowawczym, Warszawa 2019.

7 Ustawa z dnia 17 listopada 1964 roku - Kodeks postępowania cywilnego, Dz.U. z 1964 r. $\mathrm{Nr} 43$, poz. 296 ze zm.

8 Ustawa z dnia 6 lipca 1982 roku o księgach wieczystych i hipotece, Dz.U. z 1982 r. Nr 19, poz. 147 ze zm. 
Piotr Hofmański, analizując powyższe regulacje, stwierdza, że skoro

przepis art. 291 k.p.k. przewiduje możliwość zabezpieczenia majątkowego z urzędu, należy przyjąć, że także z urzędu powinien nastąpić odpowiedni wpis do księgi wieczystej. Pomimo braku w Kodeksie karnym wykonawczym odpowiednika poprzednio obowiązującego art. $131 \S 1$ Kodeksu karnego wykonawczego z 1969 roku', sąd lub prokurator, który wydał postanowienie o zabezpieczeniu, może przesłać tytuł wykonawczy bezpośrednio organowi właściwemu do prowadzenia księgi wieczystej z nakazem dokonania stosownego wpisu ${ }^{10}$.

Przytoczone stwierdzenie nawiązuje $\mathrm{w}$ istocie do zagadnień natury semantycznej, bedącej osią rozważań powyższej opinii. Trudno się jednak zgodzić, że organ procesowy dokonujący zabezpieczenia może ,nakazać” dokonania wpisu z urzędu. Zarówno sąd karny, jak i — przede wszystkim — organ prokuratury, będą tu pełnić jedynie rolę wnioskodawców. Ocena zasadności wniosku należeć będzie do sądu dokonującego wykładni operatywnej, w wyniku której wniosek może zostać zwrócony jako nie spełniający wymogów formalnych lub oddalony na ogólnych zasadach dotyczących wszystkich innych stron procesu cywilnego. Wniosek o wpis zabezpieczenia do księgi wieczystej zostaje rozpoznany przez odrębny organ sądowy w ramach procedury cywilnej (nie w procedurze karnej). Postanowienie o zabezpieczeniu i wpis hipoteki dokonywane są w odrębnych postępowaniach i przez inne organy. Organ postępowania karnego będzie natomiast w postępowaniu cywilnym stroną procesową, która zobowiązana jest do spełnienia ścisle określonych wymogów formalnych.

Wniosek o wpis zostanie uwzględniony, o ile postanowienie o zabezpieczeniu spełni kryteria merytoryczne, dlatego też winno:

a) dokładnie wskazywać nieruchomość włącznie z jej położeniem,

b) wskazywać przysługujący oskarżonemu udział we współposiadaniu określonej nieruchomości,

c) określać numer księgi wieczystej,

d) precyzować sumę, do wysokości której hipoteka ma zabezpieczać karę grzywny lub inne roszczenia majątkowe, w tym także środki kompensacyjne wymienione w art. $291 \S 1$ k.p.k. ${ }^{11}$

Konkretne wymagania stawia postanowieniu o zabezpieczeniu rozporządzenie Ministra Sprawiedliwości z dnia 7 kwietnia 2016 roku - Regulamin wewnętrznego urzędowania powszechnych jednostek organizacyjnych prokuratury ${ }^{12}$. W § 204 rozporządzenia określono elementy składowe postanowienia o zabezpie-

9 Ustawa z dnia 6 czerwca 1997 roku — Kodeks karny wykonawczy, Dz.U. z 1997 r. Nr 90, poz. $557 \mathrm{ze}$ zm.

10 J. Hofmański, Komentarz do art. 291 k.p.k., [w:] Kodeks postępowania karnego Komentarz, t. 1, red. P. Hofmański, Warszawa 2007, s. 1295.

11 Komenatrz do art. 292 k.p.k., [w:] Kodeks postepowania karnego. Komentarz, red. J. Skorupka, Waszawa 2020; por. F. Zedler, Postępowanie zabezpieczajace, t. 1, Toruń 1995, s. 69.

12 Rozporządzenie Ministra Sprawiedliwości z dnia 7 kwietnia 2016 roku - Regulamin wewnętrznego urzędowania powszechnych jednostek organizacyjnych prokuratury, Dz.U. z 2017 r. poz. 1206 
czeniu majątkowym. Przepis wymaga, aby w postanowieniu o zabezpieczeniu majątkowym organ wymienił ,wszystkie tytuły zabezpieczenia mające zastosowanie w sprawie, wskazał mienie podlegające zajęciu i sposób jego zajęcia oraz określił kwotowo przedmiot, sposób i zakres zabezpieczenia"13. W ust. 3 przepisu czytamy między innymi, że organ jest zobowiązany „wskazać szacunkową wartość nieruchomości, ruchomości i praw majątkowych podlegających zabezpieczeniu", natomiast $\mathrm{w}$ ust. 4, że „w razie gdy określenie nawet szacunkowej wartości mienia wymaga wiadomości specjalnych, jego zabezpieczenie powinno być poprzedzone uzyskaniem opinii biegłego, w której wartość tego mienia zostanie wskazana"14.

Organ procesowy, najczęściej prokurator, jest zobowiązany do oszacowania nie tylko grzywny, której wymierzenie w procesie będzie wnioskował, ale także oceny szkód i korzyści majątkowych, które podlegać będą zwrotowi na mocy końcowego orzeczenia sądowego. Zgodnie z treścią art. $110^{1}$ ustawy o księgach wieczystych i hipotece ,wierzyciel może żądać wpisu hipoteki przymusowej na sumę nie wyższą niż wynikająca $\mathrm{z}$ treści dokumentu stanowiącego podstawę jej wpisu do księgi wieczystej”. W tym przypadku dokumentem zawierającym sumę hipoteki będzie postanowienie o dokonaniu zabezpieczenia. Stosując cytowany przepis, wypada nadmienić, że jeśli z postanowienia o zabezpieczeniu nie będzie wynikała wysokość sumy hipoteki, to nie może ona przewyższać zabezpieczonej wierzytelności więcej niż o połowę, czyli na przykład kwotowo określonej grzywny czy też kwotowo określonej szkody wraz z roszczeniami o świadczenia uboczne określonymi w postanowieniu (na przykład wraz z kosztami egzekucji wymienionych kwot) stanowiącym podstawę wpisu hipoteki na dzień złożenia o niego wniosku ${ }^{15}$. Orzecznictwo Sądu Najwyższego wskazuje wprost, że przewidziane $\mathrm{w}$ art. $110^{1}$ ustawy o księgach wieczystych i hipotece określenie „suma nie wyższa niż wynikająca z treści dokumentu stanowiącego podstawę wpisu" odnosi się także do postanowienia prokuratora (art. 110 pkt 2 ustawy) ${ }^{16}$. Ustawodawca wskazuje na ustalenie sumy hipoteki wynikającej z treści dokumentu stanowiącego podstawę wpisu hipoteki, a w tym wypadku postanowienia o ustanowieniu zabezpieczenia ${ }^{17}$.

(wydane na podstawie art. $36 \S 1$ ustawy z dnia 28 stycznia 2016 roku — Prawo o prokuraturze, Dz.U. z 2016 r. poz. 177 ze zm.).

13 Z wyłączeniem art. 293 § 2 zdanie trzecie k.p.k.

14 Rozporządzenia Ministra Sprawiedliwości z dnia 7 kwietnia 2016 roku - Regulamin wewnętrznego urzędowania powszechnych jednostek organizacyjnych prokuratury, Dz.U. z 2017 r. poz. 1206.

15 Por. art. $110^{1}$ ustawy z dnia 6 lipca 1982 roku o księgach wieczystych i hipotece, Dz.U. z 2019 r. poz. 2204 ze zm.

16 Wysokość sumy hipoteki a postanowienie prokuratora, zob. postanowienie Sądu Najwyższego - Izba Cywilna z dnia 5 czerwca 2019 roku, V CSK 145/18.

17 E. Gniewek, Wspótczesny model hipoteki - zasadnicze zręby konstrukcji, ,, Monitor Prawniczy" 2011, nr 4. 
W przypadku hipoteki przymusowej konieczne będzie:

a) wskazanie sumy hipoteki,

b) jej waluty,

c) wskazanie wierzyciela hipotecznego,

— którym jest pokrzywdzony w zakresie roszczeń o charakterze kompensacyjnym

- lub Skarb Państwa, gdy chodzi o grzywny.

Podkreślić wypada, że z art. $293 \S 2$ k.p.k. wynika, że suma hipoteki winna zostać oznaczona przez prokuratora lub sąd karny w postanowieniu o ustanowieniu zabezpieczenia ${ }^{18}$. Ponadto w postanowieniu z dnia 5 czerwca 2019 roku (V CSK 145/18 ${ }^{19}$ ) Sąd Najwyższy wskazał, że wymaganie określenia tej sumy można wyprowadzić $\mathrm{z}$ właściwych przepisów o hipotece, to jest $\mathrm{z}$ treści art. $110^{1}$ zdanie pierwsze $\mathrm{w}$ zw. $\mathrm{z}$ art. 110 pkt 2 oraz art. 68 ust. 2 zd. 1 ustawy o księgach wieczystych i hipotece ${ }^{20}$. Żródłem ustalenia wysokości sumy hipoteki, która zostaje ujawniona we wpisie w księdze wieczystej, jest treść postanowienia prokuratora lub sądu karnego ${ }^{21}$. Głównym problemem interpretacyjnym w cytowanym orzeczeniu były granice wykładni postanowienia o zabezpieczeniu, a w szczególności odpowiedź na pytanie, czy oznaczenie maksymalnej kwoty należności, które mają być objęte zabezpieczeniem hipotecznym, zostałoby odczytane jako wskazanie wymaganej sumy hipoteki ${ }^{22}$.

\section{ZABEZPIECZENIE NA NIERUCHOMOŚCI JAKO PROBLEM INTERPRETACYJNY}

Sąd Najwyższy dopuścił kognicję sądu wieczystoksięgowego w przedmiotowym zakresie w rozumieniu art. $626^{8} \S 2$ k.p.c. ${ }^{23}$. Zarówno SN, jak i autor glosy do cytowanego orzeczenia, przyjęli dopuszczalność interpretacji celowościowej $\mathrm{z}$ uwagi na potrzebę efektywności środków zabezpieczenia stosowanych w ramach postępowania karnego, uznając konieczność zastosowania tej interpretacji, a tym samym ukazując pragmatyczny sens zaproponowanej argumentacji. Ich zdaniem ograniczenie interpretacji jedynie do reguł semantycznych, syntaktycznych i logicznych odnoszących się do zagadnień związanych z dyrektywami interpretacji

18 Postanowienie Sądu Najwyższego z dnia 5 czerwca 2019 roku, V CSK 145/18.

19 T. Czech, Zbiorcza hipoteka przymusowa w postępowaniu karnym. Glosa do postanowienia Sądu Najwyższego z dnia 5.06.2019 r., V CSK 145/18, „Przegląd Sądowy” 2020, nr 3, s. 110-118.

20 Ibidem.

21 Ibidem.

22 Ibidem.

23 Ibidem. 
językowej w odniesieniu do prezentowanych regulacji, mogłoby prowadzić do rezultatów podważających sprawność polityki karnej24.

Takie stanowisko może budzić uzasadnione kontrowersje. Dopuszczalność różnych reguł i metod interpretacyjnych w przypadku niewskazania wprost sumy hipoteki wyraźnie stawia prokuratora na uprzywilejowanej pozycji w kontradyktoryjnej procedurze cywilnej. W konsekwencji, wbrew twierdzeniom glosatora, prowadzi to do zagrożenia praw i wolności obywatelskich. Wykładnia in favorem fisci dodatkowo obniża wymagania jakościowe dla pracy prokuratury i sądów karnych. Dzieje się tak dlatego, że merytoryczne błędy postanowienia o ustanowieniu zabezpieczenia mogą zostać naprawione poprzez zastosowanie z urzędu interpretatio sanitatis, naprawiającej błędy prokuratury w kontradyktoryjnym postępowaniu o wpis zabezpieczenia do ksiegi wieczystej, co uzasadnione jest postulatem sprawności polityki karnej ${ }^{25}$. Powyższe nie wydaje się wpływać korzystnie na realizację prawa do obrony podejrzanego/oskarżonego.

W sytuacji, w której nie ustalono osoby pokrzywdzonego, nie będzie dopuszczalne zabezpieczenie poprzez ustanowienie hipoteki przymusowej zabezpieczającej roszczenia o charakterze kompensacyjnym ${ }^{26}$. Nie może ujść uwadze organu procesowego, że w ramach jednej hipoteki przymusowej nie można zabezpieczyć dwóch odmiennych rodzajowo wierzytelności, jak przykładowo grożącej grzywny i świadczenia pieniężnego, naprawienia szkody oraz przepadku itp. Nie jest dopuszczalne ustanowienie jednej hipoteki, która ma zabezpieczać zbiorowo należności Skarbu Państwa oraz podmiotów pokrzywdzonych, a w szczególności tych, którzy nie zostali zidentyfikowani ${ }^{27}$. W przypadku konieczności zabezpieczenia odmiennych rodzajowo wierzytelności liczba hipotek przymusowych musi odpowiadać liczbie roszczeń o odmiennym charakterze ${ }^{28}$.

Sąd Najwyższy w cytowanym uprzednio postanowieniu z dnia 5 czerwca 2019 roku (V CSK 145/18) wyraził odmienny pogląd. Stąd za autorem glosy, Tomaszem Czechem, wypada krytycznie ocenić pogląd dopuszczający ustanowienie zbiorczej hipoteki przymusowej na rzecz Skarbu Państwa w celu zabezpieczenia wierzytelności przysługujących różnym podmiotom (pokrzywdzonym, Skarbowi Państwa, podmiotom nieoznaczonym lub nieustalonym $)^{29}$. Sąd Najwyższy dopuścił bowiem wpis hipoteki przymusowej na podstawie postanowienia prokuratora, w którym ustanowiono zabezpieczenie przyszłych kar grzywny grożących właści-

24 Ibidem.

25 Ibidem; M. Matczak, Summa iniuria. O błędzie formalizmu w stosowaniu prawa, Warszawa 2007, s. 33 n.; zob. także T. Czech, Zbiorcza hipoteka przymusowa ..., s. 110-118.

26 R. Seweryn, Wybrane zagadnienia dotyczace zabezpieczenia majątkowego, ,Monitor Prawniczy” 2013, nr 5, s. 245-254.

27 A. Rogowska, B. Rogowski, I. Zduński, Korzystanie przez prokuratora z ksiąg wieczystych — zabezpieczenie majątkowe, „Przegląd Sądowy” 2011, nr 11-12, s. 63-77.

28 Ibidem.

29 T. Czech, Zbiorcza hipoteka przymusowa..., s. 110-118. 
cielowi nieruchomości (będącemu jednocześnie podejrzanym/oskarżonym). Sąd nie dostrzegł przeszkód również dla zabezpieczenia takim postanowieniem obowiązku naprawienia szkody wyrządzonej wielu pokrzywdzonym. Przyjął natomiast, że jest to możliwe na podstawie jednego tytułu, nawet wówczas, gdy w sprawie występuje wielu potencjalnych pokrzywdzonych (wierzycieli) w stosunku do jednego podejrzanego (właściciela nieruchomości) ${ }^{30}$. SN nie dostrzegł potrzeby wydawania więcej niż jednego postanowienia o zabezpieczeniu majątkowym, uznając, że w takim przypadku wierzycielem hipotecznym pozostanie Skarb Państwa, również w sytuacji wierzytelności innych podmiotów, to jest pokrzywdzonych w postępowaniu karnym ${ }^{31}$. Pogląd ten jest trudny do zaakceptowanie w obowiązującym stanie prawnym, wydaje się bowiem nie do pogodzenia z zasadą akcesoryjności i szczegółowości hipoteki (co dotyczy także hipoteki przymusowej) ${ }^{32}$.

W przypadku gdy w oznaczeniu nieruchomości zachodzi rozbieżność między treścią wniosku a treścią księgi wieczystej, to odrębności te stanowią przeszkodę dla dokonania wpisu. Wprawdzie sąd wieczystoksięgowy nie jest władny dokonać merytorycznej oceny tytułu wykonawczego, czyli postanowienia o zabezpieczeniu, ale będzie badał, o czym była mowa wyżej, czy tytuł ten zawiera essentialia istotne i konieczne do dokonania wpisu ${ }^{33}$.

Kolejnym aspektem przedmiotowych rozważań są ograniczenia w przypadku zabezpieczenia majątkowego na majątku wspólnym małżonków. Warunki zabezpieczenia majątkowego na majątku wspólnym określa art. 28 §1 k.k.w. ${ }^{34}$ Zabezpieczenie będzie możliwe, o ile nie można go dokonać na majątku osobistym podejrzanego, na wynagrodzeniu za pracę lub usługach, które podejrzany świadczy osobiście, na prawach twórcy wynalazku, wzoru użytkowego oraz projektu racjonalizatorskiego ${ }^{35}$. Na majątku wspólnym małżonków nie można zabezpieczyć środka kompensacyjnego i innych środków karnych, jak i zwrotu korzyści majątkowej z przestępstwa - ze względu na odmienny zakres zastosowania i zakres przedmiotowy przepisów art. $291 \S 1$ k.p.k. i art. $28 \S 1$ k.k.w. Przepis art. $28 \S 3$ k.k.w. uprawnia małżonka niebedącego dłużnikiem do żądania ograniczenia lub całkowitego wyłączenia możliwości zaspokojenia kary grzywny lub nawiązki z majątku wspólnego, jeżeli podejrzany małżonek nie przyczyniał się lub przyczyniał się w nieznacznym stopniu do powstania majątku stanowiącego przedmiot

30 Ibidem. Szczegółowo odnośnie do koncepcji Skarbu Państwa jako pełniącego funkcję „administratora” zabezpieczenia przymusowego zob. też postanowienie Sądu Najwyższego z dnia 5 czerwca 2019 roku, V CSK 145/18.

31 Zob. postanowienie Sądu Najwyższego z dnia 5 czerwca 2019 roku, V CSK 145/18.

32 Ibidem; zob. także J. Pisuliński, Zasada szczegółowości i akcesoryjności hipoteki po nowelizacji, [w:] Wspótczesne problemy prawa prywatnego. Księga pamiątkowa ku czci Profesora Edwarda Gniewka, red. J. Gołaczyński, P. Machnikowski, Warszawa 2010.

33 A. Rogowska, B. Rogowski I. Zduński, Korzystanie przez prokuratora ..., s. 63-77.

34 Ustawa z dnia 6 czerwca 1997 roku — Kodeks karny wykonawczy, Dz.U. z 2021 r. poz. 53.

35 Por. postanowienie Sądu Najwyższego z dnia 27 lutego 2008 roku, WZ 4/08, OSNKW 2008, nr 5, poz. 39. 
egzekucji. Przepis art. $28 \S 2$ k.k.w. wyłącza wykonanie postanowienia o zabezpieczeniu majątkowym, jeżeli małżonek skazany jest za przestępstwo, w którym pokrzywdzonym jest drugi z małżonków, lub też jeśli pokrzywdzonym jest osoba, w stosunku do której ciąży na skazanym małżonku obowiązek alimentacyjny ${ }^{36}$.

W chwili obecnej brak urządzonej księgi wieczystej lub przypadek zaginięcia księgi czy też jej zniszczenia należy do rzadkości. Wówczas zakaz zbywania lub obciążania nieruchomości będzie wykonywany tak, jak obciążenie hipoteką przymusową, z tą różnicą, że w miejsce wpisu do księgi wieczystej nastąpi dołączenie postanowienia o zabezpieczeniu jako tytułu wykonawczego do zbioru dokumentów, które księgę tę zastępują ${ }^{37}$.

Przy tej okazji warto wspomnieć o hipotece morskiej, będącej w istocie zastawem wpisanym do rejestru okrętowego. Wpis taki może nastąpić jedynie wtedy, gdy statek morski, na którym następuje zabezpieczenie, został wpisany do rejestru okrętowego ${ }^{38}$; statki niewpisane do rejestru uważane są za rzeczy ruchome. Przesłanka warunkująca wpis do rejestru okrętowego w przypadku obciążenia statku zastawem musi wyraźnie wynikać z tytułu wykonawczego, to jest z postanowienia o zabezpieczeniu ${ }^{39}$.

Postanowienie o zabezpieczeniu — zaopatrzone w klauzulę i spełniające materialne wymogi dla swojej wykonalności - stanowi podstawę dla sporządzenia przez właściwy organ procesowy wniosku o wpis w księdze wieczystej w postaci formularza KW-WPIS. Wniosek wymaga dołączenia oryginału postanowienia o zabezpieczeniu; kopia w jakiejkolwiek formie nie jest wystarczająca. Wniosek o wpis hipoteki jest zwolniony podmiotowo od opłaty sądowej. Zakres rozpoznania sądu wieczystoksięgowego jest określony dyspozycją przepisu art. $626^{8} \S 1$ k.p.c. i ogranicza się do treści wniosku, badania załączonych doń oryginalnych dokumentów i treści wymienionej we wniosku księgi wieczystej. Sąd wieczystoksięgowy jest uprawniony do kontroli poprawności informacji zawartych w przedstawionych dokumentach, co może prowadzić do oddalenia wniosku o wpis. Oddalenie nastąpi na przykład w przypadku zaistnienia sprzeczności między treścią wniosku i postanowienia, a treścią księgi wieczystej co do oznaczenia nieruchomości lub osoby, której prawo ma być wpisem dotknięte. Sąd ten nie jest upoważniony do badania przesłanek zabezpieczenia majątkowego ani też możliwości zastosowania określonego sposobu zabezpieczenia, szczególnie w zakresie grożącej kary czy też innego

36 P. Starzyński, Zabezpieczenie majątkowe w postępowaniu przygotowawczym, „Prokuratura i Prawo” 2005, nr 7-8; Metodyka postępowania w zakresie zabezpieczenia majątkowego, „Prokuratura i Prawo" 2006, nr 4, red. B. Kolasiński, s. 92-130.

37 E. Wengerek, Postępowanie zabezpieczające i egzekucyjne. Komentarz do części drugiej „Kodeksu postepowania cywilnego”, Warszawa 1972, s. 57.

38 Ustawa z dnia 18 września 2001 roku — Kodeks morski, Dz.U. z 2001 r. Nr 138, poz. 1545, art. 76-89.

39 A. Bulsiewicz, D. Kala, Zabezpieczenie majątkowe jako środek stużący wykonalności przyszłego orzeczenia o przedmiocie procesu, „Gdańskie Studia Prawnicze” 2003, nr 2, s. 227-242. 
środka o majątkowym charakterze ${ }^{40}$. Przed wydaniem postanowienia o zabezpieczeniu należy upewnić się co do tego, że opis nieruchomości jest prawidłowy: powinien pokrywać się z rzeczywistym stanem prawnym co do numeru księgi wieczystej i aktualnego stanu w zakresie własności nieruchomości. Wniosek o wpis do księgi wieczystej hipoteki przymusowej składa prokurator lub sąd rozpoznający sprawę w postępowaniu jurysdykcyjnym, które zabezpieczenie ustanawia ${ }^{41}$.

\section{PODSUMOWANIE}

Wszystkie powyżej wskazane wymogi ukazują po piewsze, równorzędność reguł interpretacji i możliwość ich zastosowania w każdej wykładni operatywnej, niezależnie od jej przedmiotu (procedury kanej czy cywilnej) i ram instytucjonalnych. Po wtóre, że modelowaniu procesu wykładni operatywnej służy klaryfikacyjna koncepcja wykładni ${ }^{42}$ i zgodnie z nią winien być prowadzony rozkład argumentacji w sytacji procesowej. Po trzecie, interpretacja karnistyczna wymaga rozstrzygnięcia interpretacyjnego na podstawie reguł pierwszego stopnia - językowych, systemowych i funkcjonalnych.

Do przedmiotu rozważań znajdują zastosowanie zarówno reguły pierwszego, jak i drugiego stopnia, właściwe modelowemu ujęciu wykładni operatywnej. Reguły interpretacyjne drugiego stopnia, w szczególności reguły preferencji, rządzą wyborem spośród znaczeń tekstu ustalonych na podstawie reguł pierwszego stopnia: językowych, systemowych i funkcjonalnych. Ze względu na charakter spraw i rolę sądu karnego oraz prokuratora w postępowaniu karnym należy przede wszystkim wskazać na znaczenie reguł semantycznych (znaczeniowych), logicznych i syntaktycznych (konstrukcyjnych) jako reguł pierwszego stopnia, a pozwalających na wyjaśnienie czynu zabronionego popełnionego przez sprawcę i ustaleniu jego winy. Reguły interpretacji językowej stanowią tu rodzaj dyrektyw wykorzystywanych przez organ stosujący prawo, podstawowych, ale koniecznych dla prawidłowego przebiegu wykładni. Kierunek orzecznictwa Sądu Najwyższego w analizowanej tu instytucji zabezpieczenia na nieruchomości wskazuje na wagę dyrektyw interpretacji funkcjonalnej, ukierunkowanej przede wszystkim na nadanie przepisom regulującym instytucję zabezpieczenia znaczenia uwzględniajacego warunki, w jakich ta instytucja ma funkcjonować. Jest to interpretacja akcentująca cel, kontekst funkcjonalny (ratio legis) i sens pragmatyczny, jaki ustawodawca chciał osiągnąć, stanowiąc przepisy o instytucji zabezpieczenia, zwłaszcza co do essentialiów tytułu wykonawczego, czyli postanowienia o zabezpieczeniu na nieruchomości.

40 R. Seweryn, op. cit., s. 245-254.

41 Uchwała Sądu Najwyższego z dnia 26 lutego 2015 roku, III CZP 96/14, OSNC 2015/9/98.

42 K. Płeszka, T. Gizbert-Studnicki, Dwa ujęcie wykładni prawa. Próba konfrontacji, „Zeszyty Naukowe Uniwersytetu Jagiellońskiego. Prace z Nauk Politycznych” 1984, z. 20. 
Odbiegając od rezultatu wykładni językowej w rozpatrywanej kwestii, uwzględnienie dyrektyw interpretacji celowościowej służyć ma celom instytucji zabezpieczenia na nieruchomości. Niezależnie zatem od sporów w doktrynie związanych z zagadnieniem sekwencyjności i ważności stosowania reguł interpretacji (reguł językowych, systemowych bądź celowościowych) oraz problematyki postulatów realizacji polityki karnej nad funkcjami gwarancyjnymi procedury karnej i cywilnej, rozważania podjęte w niniejszym szkicu wskazują na ratio praxis postanowienia o zabezpieczeniu, które winno spełniać, aby stanowić szybkie i sprawne narzędzie postępowania karnego. Wydaje się, że urzeczywistnienie w praktyce wymagań wskazanych w przedmiotowej pracy nie stanowi ,nadmiernego obciążenia" organu postępowania karnego, a co więcej, może skutecznie zabezpieczyć przedmiot wskazany w postanowieniu. Uzasadnienie orzeczenia SN wskazuje na odwołanie do reguł interpretacyjnych drugiego stopnia, w szczególności reguł preferencji, mających na celu wskazanie argumentacji zapewniającej o wartości stabilności prawa, przewidywalności orzecznictwa, bezpieczeństwa i pewności obrotu prawnego ${ }^{43}$. Niewątpliwie także dokonanie prawidłowego i wyczerpującego zabezpieczenia umożliwi sprawne zaspokojenie roszczeń tak Skarbu Państwa, jak i pokrzywdzonych w procesie karnym, a jednocześnie wzmocni praktyczny kontekst analizowanych w niniejszym szkicu reguł interpretacyjnych.

\section{SECURITY ON REAL ESTATE IN CRIMINAL PROCEEDINGS AS AN EXPRESSION OF THE EQUIVALENCE OF THE RULES OF INTERPRETATION IN THE PRACTICE OF CRIMINAL COURT DECISIONS}

\section{Summary}

The article analyses the institution of security on real estate in criminal proceedings in the context of combining in it the action of the organs of criminal proceedings in two different procedures and in two different procedural positions. The security takes place within the scope of an executive title in the form of a relevant decision and results from criminal proceedings at the in personam stage. The enforcement title obtained in criminal procedure is the basis for the entry of the compulsory mortgage to the land and mortgage register according to the regulations of civil procedure. The aim of the paper is to present the above issues both from the theoretical and practical point of view and to indicate the importance of criminal interpretation (both semantic and purposive) in land and mortgage register proceedings. Making a correct and exhaustive security should enable an efficient fulfilment of the claims of the State Treasury as well as the injured parties in criminal proceedings, and at the same time strengthen the practical context of the interpretation rules. The con-

43 Por. wyrok Najwyższego Sądu Administracyjnego z 9 kwietnia 1999 roku, II SA 333/99, niepublikowany: „W sytuacji, gdy wykładnia językowa nie pozwala na jednoznaczne rozstrzygnięcie spornej kwestii [...], należałoby sięgnąć do innych sposobów wykładni prawa, a w tym do wykładni celowościowej i systemowej [...], gdyż nie obowiązuje w tej dziedzinie hierarchia ważności sposobów inetrpretacji przepisów prawa". 
siderations of this essay point to the ratio praxis of the freezing order, which it should fulfil in order to constitute a quick and efficient tool of criminal proceedings.

Keywords: security on real estate, criminal proceedings, burden of argumentation, semantic, systematic and functional rules of interpretation

\section{BIBLIOGRAFIA}

Bulsiewicz A., Kala D., Zabezpieczenie majątkowe jako środek stużacy wykonalności przyszłego orzeczenia o przedmiocie procesu, „Gdańskie Studia Prawnicze” 2003, z. 2.

Czech T., Zbiorcza hipoteka przymusowa w postępowaniu karnym. Glosa do postanowienia Sadu Najwyższego z 5.06.2019 r., V CSK 145/18, „Przegląd Sądowy” 2020, nr 3.

Gizbert-Studnicki T., Rozkład ciężaru agumentacji w dyskursie interpretacyjnym, [w:] Studia z filozofii prawa, t. 2, red. J. Stelmach, Kraków 2003.

Gniewek E., Współczesny model hipoteki - zasadnicze zręby konstrukcji, „Monitor Prawniczy” 2011, nr 4.

Hofmański J., Komentarz do art. 291 k.p.k., [w:] Kodeks postępowania karnego. Komentarz, t. 1, red. P. Hofmański, Warszawa 2007.

Konecki J., Zabezpieczenie majątkowe w postepowaniu przygotowawczym, Warszawa 2019.

Matczak M., Summa iniuria. O błędzie formalizmu w stosowaniu prawa, Warszawa 2007.

Metodyka postepowania w zakresie zabezpieczenia majątkowego, „Prokuratura i Prawo” 2006, nr 4, red. B. Kolasiński.

Partyas W., Interpretacja karnistyczna. Studium metodologiczne, Poznań 1988.

Pisuliński J., Zasada szczegółowości i akcesoryjności hipoteki po nowelizacji, [w:] Współczesne problemy prawa prywatnego. Ksiega pamiątkowa ku czci Profesora Edwarda Gniewka, red. J. Gołaczyński, P. Machnikowski, Warszawa 2010.

Płeszka K., Gizbert-Studnicki T., Dwa ujęcie wykładni prawa. Próba konfrontacji, ,Zeszyty Naukowe Uniwersytetu Jagiellońskiego. Prace z Nauk Politycznych" 1984, z. 20.

Rogowska A., Rogowski B., Zduński I., Korzystanie przez prokuratora z ksiag wieczystych - zabezpieczenie majątkowe, „Przegląd Sądowy” 2011, nr 11-12.

Sarkowicz R., O rozumieniu spójności w interpretacji prawniczej, [w:] Teoria prawa. Filozofia prawa. Wspótczesne prawo i prawoznawstwo, Torun 1998.

Seweryn R., Wybrane zagadnienia dotyczace zabezpieczenia majątkowego, „Monitor Prawniczy” 2013, nr 5.

Starzyński P., Zabezpieczenie majątkowe w postępowaniu przygotowawczym, „Prokuratura i Prawo" 2005, nr 7-8.

Wengerek E., Postępowanie zabezpieczające i egzekucyjne. Komentarz do części drugiej Kodeksu postepowania cywilnego, Warszawa 1972.

Wronkowska S., Ziembiński Z., Teoria prawa, Warszawa 1999.

Wróblewski J., Sąowe stosowanie prawa, Warszawa 1988.

Zedler F., Postępowanie zabezpieczające, t. I, Toruń 1995.

Zieliński M., Wyktadnia prawa. Zasady, reguły, wskazówki, Warszawa 2002. 